\title{
Bazı Hakların Korunması Açısından Boşanma Sürecinde Arabuluculuk: Beklenti, Endişe ve Öneriler*
}

\author{
Mediation in the Process of Divorce for the \\ Protection of Rights: Expectations, Concerns and \\ Recommendations
}

Hilal Yazlcı**

\begin{abstract}
Öz• Arabuluculuk, özellikle medenî hukuk ilişkilerinden doğan uyuşmazlıkların çözümünde dünyada yaygın bir yöntem olarak uygulanmaktadır. Arabuluculuk, Osmanlı-Türk hukuk sisteminde tarihsel süreçte uygulama alanı bulmuştur. Bu kurumun kültürel-dinî temelleri bulunmasına rağmen, Türkiye'de pozitif hukuk düzenlemeleri içerisinde çok uzun süre yer bulamadığı görülür. Öte yandan uluslararası bazı kuruluşların tavsiye kararları ve Avrupa İnsan Hakları Mahkemesi'nin Türkiye aleyhine verdiği kararlar neticesinde arabuluculuğun düzenlenmesi ihtiyacı ortaya çıkmış ve bu konuda yakın zamanda bir kanun hazırlanmıştır. Bu kanun şiddet iddiası içeren durumlar dışında aile hukukuna ilişskin konularda da arabuluculuk yoluna başvurulabileceğini düzenlemektedir. Ancak kanun, aile arabuluculuğuna ilişsin özel hükümler getirmemiştir. Aile kurumuna anayasal düzeyde önem atfedilmiş olması, çocuk haklarının anayasa tarafından özel olarak düzenlenmiş olması ve kadının insan haklarına dair karşılaşılan sorunlar, arabuluculuk kurumunu boşanma süreçleri açısından önemli hale
\end{abstract}

* İstanbul Ticaret Üniversitesi Kadın ve Aile Uygulama ve Araştırma Merkezi ile Kadın ve Demokrasi Derneği (KADEM) ortaklığında, 8 Mart 2018 tarihinde düzenlenen "4. Toplumsal Cinsiyet Adaleti: Boşanma" kongresinde sunulmuştur.

** Arş. Gör. Dr. Karadeniz Teknik Üniversitesi Hukuk Fakültesi, Anayasa Hukuku Anabilim Dalı, Kanuni Kampusu/Trabzon, yazicihilal@hotmail.com. Orcid ID: 0000-0003-3069-9636.

\footnotetext{
\begin{tabular}{l|l}
$\begin{array}{l}\text { Başvuru: } 2 \text { Nisan } 2018 \\
\text { Kabul: } 15 \text { Haziran } 2018\end{array}$ & Copyright @ 2018 • KADEM Kadın ve Demokrasi Derneği \\
DOI: $10.21798 /$ kadem.2018141984 & kadinarastirmalari.kadem.org.tr \\
ISSN 2149-6374 • Haziran 2018 • 4 (1) • 103 - 120
\end{tabular}
} 
getirmektedir. Bu kurumun yerleşmesiyle, boşanma süreçlerinde arabuluculuğa başvurulduğunda bazı hakların korunması mümkün hale gelecektir. Ancak arabuluculuğa dair bir takım endişelerin varlığı da görmezden gelinemez. Bu endişelerin giderilmesi, tarafların ve çocuğun haklarının korunabilmesi için aile arabuluculuğunun özel bir yasal çalışmayla düzenlenmesi gerekmektedir.

Anahtar Kelimeler: Aile Arabuluculuğu, Adil Yargılanma Hakkı, Makul Sürede Yargılanma Hakkı, Kişiliğin Geliştirilmesi Hakkı, Devletin Pozitif Yükümlülüğü.

\begin{abstract}
Legal mediation is a common method to resolve disputes, especially those arising from civil law, around the world. It had also existed in one form in the Ottoman legal system. Despite the cultural and religious connection to this institution, mediation could not find a place for itself within the Turkish context. At the same time, resolutions made by some international organizations and the European Court of Human Rights decisions against Turkey showed the need to introduce the institution of mediation. The resulting law and regulations produced stipulates that mediation can be used to resolve all issues related to the family law, except cases involving allegations of violence. However, the law failed to provide special provisions for mediation involving families. The importance of the family unit, the constitutional guarantees provided for the well-being of children and problems related to the rights of women make the institution of mediation very important in regard to divorce processes. Family mediation may provide certain protection of rights of all concerned in a divorce process. However, there are very serious concerns that can not be ignored about the mediation itself. A special law regulating the process of mediation is a must for smooth running of the process, especially concerning issues related to families.
\end{abstract}

Keywords: Family Mediation, Right to a Fair Trial, Right to Trial within a Reasonable Time, Right to Free Development of Personality, Positive Obligations of the Government.

\title{
Giriş
}

Hukukî uyuşmazlıkların önemli bir bölümünün özel hukuk ilişkileri bağlamında ortaya çıktığı ve yargı açısından büyük bir yük oluşturduğu düşünüldüğünde, modern hukuk düzenlerinde bu uyuşmazlıkların giderilmesi için çözüm yolu alternatiflerinin geliştirilmesi olağan bir sonuç olarak ortaya çıkmaktadır. Bu bağlamda 
taraf iradelerinin eşitliği üzerine kurgulanan özel hukuk ilişkilerinden doğan uyuşmazlıkların arabuluculuk yöntemiyle giderilmesinin, taraflar açısından hak kayıplarına yol açmayacağı düşünülebilir. Çünkü eşit iradi güce sahip tarafların taleplerinin uzlaştırılması söz konusudur. Oysa aile hukukundan kaynaklanan ilişkilerde taraflar arasında tam bir irade eşitliğinden bahsetmek mümkün değildir. Bu sebeple hukuk düzenlerinde, taraflardan dezavantajlı olanların özel olarak korunduğu görülür. Öte yandan aile hukuku ilişkilerinden kaynaklanan uyuşmazlıklar ve boşanma süreçlerinde arabuluculuk yönteminin uygulanması halinde aile ilişkileri ve taraflar açısından oldukça olumlu sonuçlar ortaya çıkabilir. Bununla birlikte olumsuz sonuçların doğması da mümkündür. Tarafların haklarının korunması, uyuşmazlığın kısa sürede ve etkili bir şekilde, aile ilişkilerine mümkün olduğunca az zarar vererek çözülebilmesi için arabuluculuk yönteminin bu kapsamda özel olarak kurgulanması gerekmektedir.

\section{Boşanma Sürecinde Arabuluculuk Müessesesinin Önemi}

Bir uyuşmazlığın, tarafsız bir hakem gözetiminde, tarafların rıza ve anlaşmaları üzerine mahkemeye gitmeden sonlandırılması anlamına gelen arabuluculuk (Tanrıver, 2006, s. 165), çeşitli ülkelerde uzun süredir uygulanmaktadır (Demircioğlu, 2015, s.47). Ancak aile arabuluculuğu ile hukukî uyuşmazlıkların çözümünde iradi olarak başvurulabilecek bir yol olan arabuluculuğun birbirinden ayrı tutulması gerektiği de gün geçtikçe daha da önem arz eden bir konu haline gelmektedir (Parkinson, 2014, s.20). Arabuluculuk kurumunun aile kavramına vurgu yapılarak özelleştirilmesi önem arz eder. Salt hukukî bir ilişki biçimi olmayan, duygusal birçok bağla örülü bir birliktelik olan aile, arabuluculuğun da özel olarak bu yapıya uygun bir şekilde düzenlenmesini gerekli kılar. Bu çerçeve içerisinde, ihtiyaçlarının ve haklarının göz önünde bulundurulması zorunlu olan çocuklar da ailenin bir parçası ve boşanmadan etkilenen taraf olarak, aileye ilişkin konularda başvurulabilecek arabuluculuk müessesesi içerisinde özel olarak ele alınmalıdır.

Aile arabuluculuğu ayrılmakta olan eşlere, çocuklar ve malî konular ya da edinilen mülklere ilişkin düzenlemeler dâhil olmak üzere ayrılma veya boşanmadan kaynaklanabilecek konularda 
hakkaniyetli bir anlaşmaya varmalarına yardımcı olmak üzere kullanılmaktadır. Aile üyeleri içerisinde çocuklar ve gençler, üvey anne/ babalar, dede ve ninelerin de olabileceği düşünüldügünde, boşanma sürecinde arabuluculuğun özellikli bir konumda olduğu görülebilir. Arabuluculuk aile üyelerine boşanma gibi kriz dönemlerinde destek olarak birbirleri ile iletişimde kalıp karşılıklı rıza ve anlaşmaya dayanan düzenlemeler yapabilmelerine imkân tanır. Özellikle boşanma sürecinde çocukla ebeveyn arasındaki ilişkilerin sağlıklı bir şekilde yürütülmesi ve sürdürülebilir olması aile arabuluculuğunun iyi uygulanabilmesi sayesinde mümkün olabilecektir (Parkinson, 2014, s. 20).

\section{Aile Arabuluculuğunun Türk Hukukundaki Yeri}

Aile arabuluculuğu, Türk toplumunun yabancı olduğu bir kurum değildir. İslâm hukuku ve Osmanlı Devleti dönemindeki uygulamaya bakıldığında arabuluculuk işlevi görebilecek bazı kurum/ kişi ve yöntemlerin var olduğu görülebilir (Şen, 2012, s.107). Özellikle aile içi ilişkilerle alakalı sorunların çözülmesinde İslâm dininin ana kaynağı Kur'ân-ı Kerim'de bu noktada önemli hükümler yer alır. Nisâ sûresi 4. âyette "Eğer karı ile kocanın aralarının açılmasından endişeye düşerseniz, o vakit kendilerine erkeğin ailesinden bir hakem, kadının ailesinden bir hakem gönderin. İki taraf (arayı) düzeltmek isterlerse Allah aralarını bulur; şüphesiz Allah her şeyi bilen, her şeyden haberdar olandır." Burada verilen anlamıyla hakem kavramının esasen bir tür arabuluculuğa işaret ettiğini söylemek mümkündür (Şen, 2012, s. 116). Çünkü burada hakim olmayan ve tarafların iradeleriyle seçilen kimselerin, tarafların arzu ve istekleri çerçevesinde aralarını bulma anlamına gelebilecek bir faaliyetin yürütülmesi tavsiye edilmiştir. Bu açıdan bakıldığında hakemlik kurumunun, modern hukukun kabul ettiği arabuluculuk şartlarını sağlanmış olduğu görülür. Nisâ 128. âyette evliliğe ilişkin konuların sulh yoluyla giderilmesi açıkça teşvik edilmiştir. "Eğer bir kadın kocasının geçimsizliğinden yahut kendisinden yüz çevirmesinden endişe ederse, aralarında bir sulh yapmalarında onlara günah yoktur. Sulh (daima) hayırlıdır. Zaten nefisler kıskançlığa hazırdır. Eğer iyi geçinir ve Allah'tan korkarsanız şüphesiz Allah yaptıklarınızdan 
haberdardır.” Âyetler çoğaltılabileceği gibi İslâm hukukunun önemli bir başka kaynağı olan sünnette de birçok sulh uygulamasina yer verildiği görülebilir (Şen, 2012, s. 118-121). Osmanlı döneminde ise kadıların hâkim olarak uyuşmazlıkları çözmelerinin dışında, tarafları sulha davet etme ya da onların sulh yoluyla anlaşmış oldukları hususları onaylama yetkileri bulunmaktaydı (Dörtok, 2006, s. 114). Yargılama süreçlerinde kadıya yardımcı unsurlardan birisi olan muslihûn, tarafların anlaşarak uyuşmazlıkların nihayete ermesinde önemli roller üstlenmişlerdi. Aynı şekilde müftîlerin de dinî hukukî konularda dolaylı olarak mahkemeye yardımcı oldukları ve bir nevi arabulucu rolü üstlendikleri görülmüştür (Aydın, 2003, s. 343). Bu açıdan bakıldığında, tarihsel, kültürel ve hukukî temelleri bulunan, geleneğe, örf ve âdete uygun olan arabuluculuk kurumunun, bugünün modern hukuk düzenlerinin oldukça önemli bir bölümünde uygulandığı üzere Türkiye'de de yeniden canlandırılması önemlidir.

\section{Türkiye'de Arabuluculukla İlgili Gelişmeler ve Aile Arabuluculuğu}

Türkiye arabuluculuk kurumuna uzun süre mesafeli yaklaşmış olmakla birlikte son yıllarda bu konuda önemli gelişmeler yaşanmaktadır.

Türkiye'de aile arabuluculuğu ihtiyacının varlığını ortaya koyan önemli bir olay Avrupa İnsan Hakları Mahkemesi’nin(AİHM) Türkiye aleyhine vermiş olduğu oldukça önemli bir karar ile açıkça hissedilmiştir. Bu karar bir boşanma davası çerçevesinde oluşturulmuştur. Bu olayda taraflardan erkek olan eş Türkiye'de boşanma davası açmış ancak bu dava 8 yıl 6 ay sürmüştür. Ayrıca boşanma çerçevesinde ileri sürülen bazı talepler de aynı şekilde oldukça uzun bir süre karşılanmamıştır. Bu sorun AİHM'e taşınmış ve Mahkeme aile hayatının korunması hakkının (AİHS m. 8), özellikle çocuğun kişisel gelişiminin korunması hakkının ve oldukça uzun yargılama süreci sebebiyle adil yargilanma hakkının (AİHS m. 6) ihlal edildiğine ve devletin pozitif yükümlülüklerini yerine getirmediğine karar vermiştir (Cengiz Kılıç/Türkiye, B. No: 16192/06). 
Aile arabuluculuğu ve genel olarak arabuluculuk konusunda Türkiye'de yaşanan gelişmeleri önemli ölçüde etkileyen bir başka gelişme ise Avrupa Konseyi Bakanlar Komitesinin R(98)1 Sayılı Tavsiye Kararı olmuştur. Tavsiye Kararı, aile arabuluculuğu müessesesinin hangi noktalarda önem taşıyacağını oldukça güzel vurgulamaktadır. Tavsiye Kararının 7. fikrası aile arabuluculuğu kurumunun aile bireyleri arasındaki ilişkinin daha sağlıklı hale getirilmesinde, mevcut uyuşmazlığın ve etkilerinin azaltılabilmesinde, bir uzlaşmanın ortaya çıkabilmesinde, ebeveynler ve çocuklar arasındaki ilişkinin devamlılığının sağlanabilmesinde, hem taraflar hem de devlet açısından boşanma ve ayrılıktan kaynaklanan sosyal ve ekonomik yükün azaltılmasında ve eğer dava yoluna başvurulacaksa uzun yargılama süreçlerinin azaltılması noktalarında etkili olabileceğini vurgulamıştır. Aynı şekilde Avrupa Konseyi Bakanlar Komitesinin Hukuk Uyuşmazlıklarında Arabuluculuk Hakkındaki Rec (2002) 10 Sayılı Tavsiye Kararı da medenî uyuşmazlıklarda arabuluculuk kurumunun önemine vurgu yaparak bu konuda oluşturulacak yapıların hangi ilkeler çerçevesinde düzenlenmesi gerektiği üzerinde durmuştur. Bu Kararda da vurgulanan nokta, arabuluculuğun uyuşmazlığın çözüm sürecini kolaylaştırıcı etkisidir. 2008 yılında Avrupa Parlamentosu ve Avrupa Birliği Konseyi Medeni ve Ticari Hususlarda Arabuluculuğun Belirli Yönleri hakkında bir direktif yayımlamıştır (Avrupa Arabuluculuk Direktifi 2008 [21 Mayıs 2008 Tarih, 2008/52/EC Sayılı Direktif]). Bu direktif de taraflar arasında dostane bir ilişkinin var edilebilmesi ve sürekliliğin sağlanabilmesi noktasında arabuluculuğun önemini vurgulamaktadır. Esasında Türk pozitif hukukunda da bazı alternatif uyuşmazlık çözüm yöntemleri bulunmaktaydı (örneğin; Av. K. madde 35/A; CMK madde 253, 256, TKHK madde 22 gibi). Bu gelişmelerin ardından nihayetinde Türkiye'de 6325 Sayılı Kanun hazırlanmış (Hukuk Uyuşmazlıklarında Arabuluculuk Kanunu, Resmi Gazete, 22.06.2012-28331) ve aile hukukuna ilişkin konularda da arabuluculuk yönteminin uygulanması sürecine girilmiştir (Milliyet, 20.10.2017). Ancak kanun m.1/1'de tarafların üzerinde serbestçe tasarruf edebilecekleri iş veya işlemlerden doğan özel hukuk uyuşmazlıklarının çözümlenmesinde arabuluculuğun uygulanabileceğini düzenlerken, aile hukukundan kaynaklanan uyuşmazlıkları ayrıca konu edinmemektedir. Öte yandan kanun 
bu noktada yaşanacak uyuşmazlıklarda arabuluculuk yoluna başvurulmasının önünü de açmıştır. Oldukça doğru bir bakış açısıyla aile içi şiddet iddiası içeren uyuşmazlıkların arabuluculuğa elverişli olmadığı kanunla açıķ̧a vurgulanmıştır. Buna göre aile içi şiddet iddiası içermeyen aile hukukuna ilişkin konularda arabuluculuk yoluna başvurulabilecektir. Dolayısıyla boşanma sürecinde de arabuluculuk müessesesinin işletilmesi mümkün olacaktır. Boşanma sürecinde başvurulabilecek bu yolun, tarafların bazı hak ve özgürlükleri üzerinde nasıl etkileri olacağı ise çalışma kapsamında önem arz etmektedir. Maddî manevî ağır yükler içeren boşanma sürecinde tarafların ve çocukların haklarının korunmasında aile arabuluculuğunun olumlu etkileri olabileceği gibi olumsuz etkiler doğurması da muhtemel görünmektedir.

\section{Boşanma Sürecinde Bazı Hak Alanlarında Ortaya Çıkan İhlaller ve Arabuluculuk Kurumunun Olumlu Etkileri}

Aile hukukunun önemli bir parçası olan boşanma sürecinde, karşlaşılan bazı önemli sorunların çözümü için başvurulabilecek bir yol olan aile arabuluculuğu kurumunun oldukça önemli bir ihtiyacı karşlayacağı açıktır. Boşanma sürecinden etkilenecek olan süjeler olarak eşler ve çocukların bazı haklarının korunması noktasında arabuluculuk faaliyetinin sağlayacağ faydalar dikkat çekicidir. Bu faydalar özellikle anayasanın özel önem atfettiği ailenin korunması ile kadın ve çocuk hakları noktasında yoğunlaşmaktadır. İlk fayda özel hayatın gizliliği ve ailenin korunması hakkı kapsamında ortaya çıkmaktadır. Boşanma süreçlerinde aile mahremiyetinin gizli kalabilmesi önemlidir. Bu gizlilik sağlanamadığında anayasanın 20. maddesinde düzenlenen özel hayatın gizliliği hakkı çoğu zaman ihlal edilebilmekte ve taraflar maddî ve manevî zarar görebilmektedirler. Ayrıca bir boşanma söz konusu olduğunda, bu süreçte bir ailenin varlığı söz konusudur ve boşanma sürecinde yaşanacak her türlü olumsuzluk aynı zamanda anayasanın 41. maddesinde oldukça büyük önem atfedilen aile hayatı ve ailenin korunması haklarının ihlaline sebebiyet verebilmektedir. Bu noktada arabuluculuk kurumunun gizlilik açısından bir boşanma davasına oranla daha fazla koruyucu özellik göstereceği söylenebilir. Zira Arabuluculuk Kanunu 4. 
ve 5. maddeler ile ilgili Yönetmeliğin 6. ve 7. maddeleri arabuluculuk sürecinde gizliliğe ilişkin önemli düzenlemeler içermektedir (Hukuk Uyuşmazlıklarında Arabuluculuk Kanunu Yönetmeliği, Resmi Gazete, 26.01.2013-28540). Buna göre "Taraflarca aksi kararlaştırılmadıkça arabulucu, arabuluculuk faaliyeti çerçevesinde kendisine sunulan veya diğer bir şekilde elde ettiği bilgi ve belgeler ile diğer kayıtları gizli tutmakla yükümlüdür. Aksi kararlaştırılmadıkça taraflar ve görüşmelere katılan diğer kişiler de bu konudaki gizliliğe uymak zorundadırlar.” Aynı şekilde arabuluculuk sürecinde ortaya çıkan beyan ve belgelerin daha sonra, sürece katılan kişilerce delil olarak kullanılması da yasaklanmıştır.

Anayasada 2010 yılında yapılan bazı değişiklikler ise çocuklarla ilgili oldukça önemli hak kategorilerinin anayasaya dâhil edilmesini sağlamıştır. Bu bağlamda yine 41. maddeye yapılan eklerle çocuğun korunması, anne ve babasılla kişisel ilişki kurması ve sürdürebilmesi hakları, devletin açık pozitif yükümlülüğünü gerektiren sosyal ve ekonomik haklar kategorisinde yer almıştır. Boşanma süreçlerinde özellikle çocuğun zarar görmesi, özel önlemler alınmadıkça her zaman mümkün olabilmektedir. Arabuluculuk sayesinde uzlaşma ve anlaşmanın sağlanması yoluyla çocuğun bu haklar yönünden korunması daha mümkün hale gelecektir. Zira arabuluculuk kurumunun yaygın olarak uygulandığı karşılaştırmalı örneklerde çocukların durumunun özel olarak ele alındığı ve haklarının korunması için tedbirlerin özel olarak ele alındığı görülmektedir (Parkinson, 2014, s.129).

Diğer taraftan boşanma davası sürecinde çocuğun ve tarafların kişiliğini geliştirme hakkının ihlal edildiği de ileri sürülebilir (Gören, 1992, s.173-174). Yine AİHS ve anayasada güvence altına alınmış olan bu hak, uzun yargılama süreçleri neticesinde ihlal edilebilmektedir. Çocuğun ve tarafların hukukî durumunun belirsizliği ve yaşanan çekişmeli süreç, özellikle çocuğun psikolojisi üzerinde uzun süre olumsuz etkiler doğurarak bu hakkın ihlaline yol açabilmektedir. Anayasanın 10. maddesinde 2010 yılında yapılan düzenleme çerçevesinde çocuk, devlet tarafindan özel olarak korunması gereken gruplar arasında açıkça sayılmıştır. Buna göre boşanma sürecinin olumsuz etkilerinden korunma da çocuğun en temel haklarından biri 
olarak değerlendirilebilir. Bu noktada arabuluculuk kurumunun en önemli etkilerinden birisi ortaya çıkmaktadır. Arabulucunun uzlaştırıcı etkisi sayesinde çocukla ilgili meselelerin taraflar açısından önemli ve öncelikli hale gelmesi mümkün olabilecek ve çocuğun üstün yararı korunacaktır.

Kişiliğin geliştirilmesi hakkı, modern hukukun tanıdığı, insanın kendi kişiliğini gerçekleştirebilmesi, yeteneklerini gösterebilmesi, geleceğini planlayabilmesi, dış dünya ile sağlıklı ilişkiler kurabilmesi, kişiyi diğerlerinden ayıran tüm özellikleriyle birlikte tanınmasını sağlayıcı bir haktır (YHGK E. 2014/2-889, K. 2015/2011, T. 30.09.2015). Alman Anayasası 2. maddesinde dokunulmaz ve değiştirilmesi yasak haklar arasında yer alan, 1982 Anayasası'nın 17. maddesinde korunan kişiliğin (serbestçe) geliştirilmesi hakkı, esasen bütün diğer hakların anlamlı bir şekilde hayata geçmesini sağlayabilecek kurucu bir hak olarak değerlendirilebilir (Gözler, 2011, s. 525). Kişiliğin geliştirilmesi hakkının korunması boşanma sürecinde tarafların her ikisi için de önemlidir. Ancak bu hakkın korunmasının, özellikle kadın tarafı açısından özel bir önem taşıdığı söylenebilir. Boşanma sürecinin uzunluğu ve bu süreçte ortaya çıkan belirsizlik, kişilerin sonraki hayatlarının düzene sokulması ve geleceğin planlanabilmesi bağlamında olumsuz sonuçlar doğurabilmektedir. Türk toplumu açısından bakıldığında, kadının çoğunlukla ekonomik anlamdaki geçiminin evli olmadan önce aile, evlilik sonrasında ise kocaya ait olduğu düşünüldüğünde, boşanma süreci ve sonrasında hayatın adeta yeniden planlanıp kurgulanması önemli bir sorun haline gelmektedir. Aile içi meselelerin bir davaya konu edilmiş olması çekişmeyi daha da büyütebilmektedir. Boşanma sürecinde arabuluculuk hem bu çekişmenin azaltılması hem sürecin kısalmasına yardımcı olurken, kişilerin ayrılık sonrası hayatlarında geleceklerini kurgulayabilmelerinde olumlu bir moral etki doğurabilecektir. Boşanma sürecindeki belirsizlik ve sürecin uzunluğu, koca olan eşin kendi hayatını yeniden planlaması noktasında da sorunlar yaratabilir. Çocuğun bu süreçteki durumu ise daha da büyük önem arz eder. Boşanma sürecinde yaşanacak olan her türlü sorun, çocuğun gelişimi açısından oldukça olumsuz sonuçlar doğurabilmektedir (Türkarslan, 2007, s. 99-108). Kişiliğini inşa sürecinde olan çocuk, 
maddî ve manevî yönleriyle tümüyle aileye ihtiyaç duyar bir pozisyondadır. Bu süreçte kişiliğinin, maddî ve manevî varlığının korunup geliştirilmesi için ihtiyaç duyduğu her şey aile tarafindan karşllanmaktadır. Boşanma sürecinde ise bu durum değişmekte, çocuk her mânada belirsiz bir sürecin içine girmektedir. Devlet tarafından özel olarak korunması gereken gruplar içerisinde sayılan çocuğun (Anayasa m. 41), aile arabuluculuğu sayesinde boşanmanın olumsuz etkilerinden önemli ölçüde korunacaktır.

Arabuluculuk kurumunun olumlu etkilerinin görüleceği bir başka hak ise adil yargılanma hakkı çerçevesinde değerlendirilen makul sürede yargılanma hakkı olacaktır. Türkiye'de yargılama süreçlerinin genel olarak uzun oluşuna dayalı olarak çoğunlukla Anayasanın 36. ve Avrupa İnsan Hakları Sözleşmesi'nin 6. maddesinde güvence altına alınan makul sürede yargılanma hakkının ihlali (İnceoğlu, 2013, s. 370) sorunuyla karşı karşıya kalınmaktadır. Bu konuda özellikle AİHM'in Türkiye hakkında vermiş olduğu ihlal kararları bulunmaktadır. Boşanma davalarında da kısa sürede bir yargı kararının elde edilememesi kişilerin uyuşmazlıklarının makul sürede giderilmesini engellemektedir. Arabuluculuk, tarafların karşılıklı olarak anlaşmalarına imkân tanıyacağından, çekişmeli süreçleri büyük ölçüde ortadan kaldırarak daha kısa bir sürede eşlerin ve çocuğun hukukî durumlarının kesinleşmesine imkân verecektir.

Aile arabuluculuğu kurumunun getirilmesi noktasında devletin durumunun da yine hak ve özgürlükler çerçevesinde değerlendirilmesi gerekir. Kişilerin hak ve özgürlüklerinin korunup geliştirilmesi noktasında taraf olunan insan hakları sözleşmeleri ve anayasanın devlete yüklemiş olduğu pozitif yükümlülükler bulunmaktadır. Devletler, bireylerin hak ve özgürlüklerine dokunmamakla yükümlü oldukları kadar; onların kullanılmasının önündeki engelleri kaldırmak ve kullanılabilmelerini sağlamak ve ihlalleri ortadan kaldırmak için gereken tedbirleri almakla da yükümlü kılınmıştır. Anayasanın 90. maddesinde yapılan değişiklikle de usulüne göre yürürlüğe girmiş uluslararası insan hakları belgeleri iç hukuka üstün tutularak, devletin bu yönde adımlar atması adeta zorunlu hale getirilmiştir. Özellikle yukarıda değinilen hak alanlarında eşlerin ve çocuğun haklarının korunabilmesi açısından arabuluculuk kurumunun 
oluşturulması, devlete anayasanın yüklemiş olduğu pozitif bir yükümlülük olarak da değerlendirilebilir. Bu yükümlülük aynı zamanda anayasanın 10. maddesinde eşitlik ilkesini düzenleyen hükümler çerçevesinde de söz konusudur. Bu madde kadın ve çocuğun korunması noktasında pozitif ayrımcılığı düzenlemiş, devletin tüm kurumları ve anayasa altı normlar bağlamında bağlayıcılığı olan önemli bir anayasal ilkedir. O halde aile hukukundan kaynaklanan ve boşanma sürecinde yaşanan hak ihlallerinin giderilmesi noktasında da devleti pozitif yükümlü olarak değerlendirmek mümkündür. Devletin pozitif yükümlü olması ise söz konusu hak ihlalinin önlenmesi ve giderilmesi için somut bir tedbir almasını, düzenleme yapmasını zorunlu kılar (Boyar, 2013, s. 71).

Arabuluculuk kurumunun başkaca olumlu etkilerinden bahsetmek de mümkündür. Arabuluculuk sürecinde tarafların aynı zamanda bir nevi psikolojik yardım ya da danışmanlık hizmeti alabileceklerinden bahsedilebilir. Bu durum bazen tarafların sorunlarını hallederek evlilik birliğinin devamı yönünde karar vermelerini kolaylaştırabilecektir. Arabuluculuğun başka bir olumlu etkisi ise mahkemelerdeki iş yükünü büyük ölçüde azaltacak olmasıdır. İstatistikî verilere göre Türkiye'de her yıl yaklaşık olarak 130 bin boşanma gerçekleşmekte ve her yıl bu sayı artış eğilimi göstermektedir (TÜİK, Evlenme ve Boşanma İstatistikleri, 2016). Arabuluculuk yoluyla aile hukukuna ve boşanmaya ilişkin birçok uyuşmazlık mahkemelere gitmeden çözüleceğinden bu bağlamdaki iş yükünün de azalacağı söylenebilir.

\section{Boşanma Sürecinde Arabuluculuk Müessesesine İlişkin Bazı Endişeler}

Arabuluculuk kurumu yukarıda sıralanan beklentileri karşılayacak olsa da bazı endişeleri de beraberinde getirmektedir. Bunlardan ilki, uzun yargılama süreçlerini ortadan kaldıracağı düşünülen arabuluculuğun her boşanma açısından olmasa da bazı vakalarda boşanma süreçlerini uzatacağı endişesidir. Her boşanma uyuşmazlığ̣ açısından arabuluculuğun olumlu bir etki doğuracağı şüphesiz iddia edilemez. Böyle bir durumda hem sorun çözülememiş olacak hem de boşanma davası süreci uzayabilecektir. Bu durumda süreci 
kısaltmak gibi bir etki doğurması beklenen arabuluculuğun tam tersi yönde bir etki doğurması mümkün olabilecektir.

Bir başka olumsuzluk ise yeterli hukukî bilgiye sahip olmayan kimselerin tarafların hak kaybına sebep olabilecek olmasıdır. Her ne kadar arabulucu olacak kişilerin belli nitelikler taşıması ve hukuk fakültesi mezunu olması şartı aranmış olsa da (Yönetmelik, m. 24/2/b) aile hukuku, şiddet, istismar gibi oldukça önemli bazı konular açısından özel ve kapsamlı bir eğitime tabi tutulmamaları halinde taraflar ve çocuk açısından önemli hak kayıplarının ortaya çıkmasına sebep olmaları söz konusu olabilecektir.

Ayrıca Türkiye'de kadının insan haklarına ilişkin yerleşmiş olumsuz bakış açısı bir yanda dururken, yeterli düzeyde insan hakları nosyonu olmayan kişilerin yürüteceği arabuluculuk süreci, bu alanda daha büyük hak kayıplarına yol açabilecektir. Her ne kadar şiddet temelli vakalar arabuluculuğun dışında tutulmuş olsa da şiddetin çok çeşitli şekillerde gerçekleşebileceği düşünüldüğünde şiddetin varlığının tespitinin ne kadar önemli olduğu ve bu konuda özel bir bilgi birikiminin gerekliliği görülecektir. Kadına yönelik şiddete ilişkin yargı kararları açısından dahi önemli sorunların olduğu düşünüldüğünde bu konuda da önemli hak kayıplarının yaşanabileceği söylenebilir.

Arabuluculuk pozitif düzenlemeler çerçevesinde her ne kadar tarafların iradelerine ve tarafların eşitliğine dayandırılmış bir kurum olsa da kültürel, sosyolojik, ekonomik ve psikolojik birçok faktörün etkisiyle özellikle kadının baskı altında hissetmesini mümkün hale getirebilecektir. Bu durumda taraflar arasındaki güç dengesizliği, arabuluculuk sürecinin, iradi gibi görünse de kadın aleyhine sonuçlanmasina sebep olacaktır.

Türkiye'de evliliğin hukukî boyutuna ilişkin genel bilgi düzeyi değerlendirildiğinde, özellikle kadınların bu müessese içerisinde sahip oldukları haklara ilişkin önemli bir bilgi eksikliğinin olduğu görülür. Bu eksikliğin, özellikle evlilik ve boşanmanın malî boyutuyla ilgili olarak daha yoğun bir şekilde ortaya çıktığı söylenebilir. Boşanmada malî hükümler noktasında tarafların serbest iradelerinin ve tercihlerinin ön planda olduğu düşünüldüğünde (Bilgin, 2016, s.35) 
bu durumun özellikle bazı malî hakların kaybı noktasında hakkaniyete uygun olmayan sonuçlar doğurabileceği söylenebilir. Burada yine kadının hem konuya ilişkin genel bilgisinin eksikliği hem de toplumsal cinsiyet rollerinin etkisi, sosyo-kültürel baskı ya da diğer eşin baskısı gibi faktörlerin etkili olabileceği ve kadının serbest iradesi ve tercihinin onun aleyhine bir şekilde yönlendirilmesi ihtimali söz konusu olabilecektir. Arabuluculuk sürecinde ise hukukî - teknik yönü ağır basan böyle bir konunun taraflar açısından tümüyle hakkaniyetle sonuçlandırılamayacak olması, kayda değer bir endişe olarak değerlendirilebilir.

Bir başka endişe ise arabulucunun yeterli düzeyde güvenceli bir konuma kavuşturulmaması halinde etki ve baskı altına alınabilmesi ihtimalinin söz konusu olabileceğine ilişkindir. Davaların mahkeme-hâkim önünde görülmekte olması ve bireylerin bu kurumlara ilişkin algısı taraflarda kurallara uyma, saygı gösterme, devletin koruyucu gücünü hissetme gibi etkiler yaratabilmektedir. Ancak arabulucu ile ilgili olarak aynı ya da benzer bir algının yaratılması oldukça zordur. Bu durumda arabulucu etki ve baskı altına alınabilecektir.

\section{Sonuç ve Öneriler}

Arabuluculuk sürecinde yukarıda sıralanan endişelerin giderilmesi için bazı öneriler sunulabilir.

İlk olarak arabulucu olabilmek için hukuk öğrenimine sahip olmanın yanında; arabuluculuk eğitim süreçlerinin insan hakları ve özellikle kadın ve çocuk hakları açısından zenginleştirilmesi gerekmektedir. Bu noktada kadına yönelik şiddet, şiddetin türleri, çocuk istismarı, aile psikolojisi gibi temel bazı konularda arabulucuların özel ve kapsamlı bir eğitim sürecine tabi tutulmaları gerekir.

Arabuluculuk süreçlerinin özellikle taraflardan birisi ve çoğunlukla da muhtemelen kadın tarafından iyi yürütülememesi, tarafın zayıf olması veya yeteri kadar bilgi sahibi olmaması nedeniyle hakkaniyete uygun olmayan sonuçların ortaya çıkması mümkün olabilir. Taraflar açısından yaşanabilecek hak kayıplarının önlenmesi için sürece bir avukatın dâhil edilmesi, taraflar bunu sağlayamadığı 
takdirde baro tarafindan görevlendirilme yapılması zorunluluğu da düşünülebilir.

Aile kurumunun önemi ve özel oluşu, ülkenin sosyo - kültürel yapısı sebebiyle çocuk ve kadın haklarının ayrıca korunması gerektiğinden hareketle aile ve boşanma arabuluculuğu ile ilgili ayrı bir kanun hazırlanması da gerekmektedir. Bu kanun, özellikle aile hukukuna ilişkin hangi konuların arabuluculuk kapsamına alınacağını, şiddetin varlığının tespiti için her vakada ayrıca inceleme yapacak bir kişinin sürece dâhil edilmesini zorunlu tutmalıdır. Veyahut da şiddet konusunda arabulucunun ayrıntılı bir eğitim sürecine tabi tutulması gerekir. Burada alternatif olarak ayrı bir kanunî düzenleme yerine mevcut kanunda aile arabuluculuğu için ayrı bir bölümün düzenlenmesi de düşünülebilir.

Arabuluculuk güvenceli bir statüye kavuşturulmalıdır. Tarafların hak ve özgürlüklerinin gerçekten korunabilmesi bakımından taraflarda, önemli ve saygın bir kurum karşısında uyuşmazlıklarını çözmekte oldukları algısının yaratılabilmesi gerekir. Ayrıca bu gereklilik arabulucuların güvenliği açısından da söz konusudur.

Sonuç olarak, aile arabuluculuğunun tarafların bazı hak ve özgürlükleri açısından oldukça olumlu etkiler yaratacak olması sebebiyle, modern hukuk sistemlerinde olduğu gibi Türkiye'de de uygulanması yararlı olacaktır. Aile arabuluculuğunun sağlıklı işleyebilmesi için ise bu konunun hukuk uyuşmazlıklarında arabuluculuk müessesesinden ayrı tutularak özel olarak düzenlenmesi ve bu düzenlemede özellikle çocuk ve kadının haklarının korunması için tedbirler alınması gerekir.

\section{Mediation in the Process of Divorce for Protection of Rights: Expectations, Concerns and Recommendations}

Legal mediation, which means the termination of a dispute with the consent and agreement of all concerned parties in the presence of an objective mediator (Tanriver, 2006, p. 165), has been implemented in various countries for a long time (Demircioğlu, 2015, p.47). There has been significant progress in Turkey in this regard in recent years. The European Court of 
Human Rights (Cengiz Kılıç/Turkey, B.No: 16192/06, p.133) and The Committee of Ministers of the Council of Europe (Recommendation numbered $R$ (98) 1) have provided recommendations on this matter; hence, Law No. 6325 was prepared and the implementation process of the mediation method in matters regarding Law of Domestic Relations started.

Mediation is not a new institution for our legal system. The institution of mediation, which has a historical, cultural and legal basis, and adheres to our traditions and customs, should be restored in Turkey since it has been utilized in quite a significant number of modern legal systems today.

It is obvious that the institution of family mediation, an issue of special importance in cases of divorce, will satiate an immense societal need. Firstly, mediation will allow families to keep their privacy during the divorce process. Secondly, it is suggested that the trial process can be shortened considerably through mediation. Considering that the excessive length of trials is a major right issue and the Article 36 of the Constitution and the Article 6 of the ECHR (İnceoğlu, 2013, p.370) mandates that trials need to be concluded in a reasonable length of time, this issue is of significant importance. Another major concern is the possible negative effects of the trial process on the personality of the still growing child, which is a violation of his/ her rights. (Gören, 1992, p.173-174). Turkey is a signatory of human rights conventions that guarantee the protection and preservation of individual rights and freedoms, and the Constitution obliges the state to guarantee these rights. Moreover, as per the amendment in Article 90 of the Constitution, the international human rights documents supersede domestic law.

Another positive effect of family mediation is that it may allow the resolution of the disagreement that sparks the demand for divorce and prevent the breakup of the family. The mediation efforts may provide a suitable environment conducive to sound communication with effective psychological support. Such an environment may encourage the two parties to resolve their differences and re-strengthen the bonds of marriage. 
While satisfying some of the expectations listed above, the process of mediation also raises some concerns. First is the concern that the lengthy trial process mediation is out to shorten may take place only in few of the cases. Another serious concern is the possibility of people without any knowledge about their legal rights and responsibilities being taken advantage of. Furthermore, considering the settled negative conception on women's human rights in Turkey, decisions taken by those who do not take rights and freedoms at the center of their deliberations may lead to an even greater injustice. Although cases that involve violence are excluded from the mediation process, violation can take place a wide variety of forms and a significant loss of rights may be experienced in this regard. Mediation may exacerbate the imbalance of power between parties and result in serious miscarriages of justice. It also may place significant pressure on women due to many cultural, sociological, economic and psychological factors. Lack of legal and technical knowledge about divorce may mean loss of financial rights during the mediation process. Yet another concern is that unless the mediator feels secure in every sense of the word, he/she may be coerced one way or another. The physical fact that trials take place in a court setting with the judge placed above all introduces an institutional formality that provides a sense of legitimacy under the full power of the state. However, the office of the mediator and the process lacks any such formality or public perception.

It is, however, possible to address such concerns by taking official action. Firstly, the training for the mediator should focus on human rights, especially concerning women and children, and a legal education needs to be a prerequisite. All sides need to be assisted by lawyers during the negotiations overseen by the mediator to prevent any loss of rights and if any one of the parties cannot afford to do so, a lawyer needs to be assigned by the local bar association.

As the family institution is unique and has its own laws and regulations, the mediation for divorce also needs its own laws 
and regulations that prioritize the protection of the rights of women and children with special allowance for the socio-cultural structure of the country. This law needs to set the extent of the mediation process and make the inclusion of an investigator to determine if any violence was involved in the case obligatory. Additionally, the institution of mediation needs to inspire public respect to ensure its effectiveness and continuation. It should instill a sense of justice and make applicants sure their rights and freedoms will be preserved. All parties need to know that they will be able to resolve their differences in front of an impartial and expert observer, which is also necessary for the safety of the mediator.

\section{Kaynakça/ References}

"Boşanma Süreci İçin Arabuluculuk Geliyor”, Milliyet Gazetesi, 20.10.2017. Avrupa İnsan Hakları Mahkemesi Kararı, Cengiz Kılıç/Türkiye, Başvuru No: 16192/06, 06.12.2011.

Avrupa Konseyi Bakanlar Komitesi Aile Arabuluculuğu Hakkındaki (98) 1 Sayılı Tavsiye Kararı, Http://www.Arabuluculuk.Adalet.Gov.Tr/Sayfalar/Proje Belgeleri/5.Pdf, (Erişim: 11.12.2017).

Aydın, Mehmet Akif. (2003). "Mahkeme", İslâm Ansiklopedisi, TDV, Cilt 27, Ankara, s. 341-344.

Bilgin, Esra Pınar Yılmaz. (2016). Türk Hukukunda Anlaşmalı Boşanma, İstanbul: On İki Levha Yay.

Boyar, Oya. (2013). "Devletin Pozitif Yükümlülükleri Ve Dolaylı Yatay Etki”, Insan Hakları Avrupa Sözleşmesi ve Anayasa: Anayasa Mahkemesine Bireysel Başvuru Kapsamında Bir İnceleme, 3. Baskı., Ed. Sibel İnceoğlu, İstanbul: Beta Bas. Yay. Dağ.

Demircioğlu, Huriye Reyhan. (2015). "Aile Hukuku Uyuşmazlıkları Bakımından 6325 Sayılı Hukuk Uyuşmazlıklarında Arabuluculuk Kanunu'nun Uygulanabilirliği”, TAAD, Yıl: 6, Sayı: 23, s. 45-84.

Dörtok, Zeynep Arabacı. (2006). "Bir Sorun Çözme Yöntemi Olarak Sulh: 18. Yüzyıl Bursa Kadı Sicillerinden Örnekler ve Düşündürdüklerı”, Ankara Üniversitesi Osmanlı Tarihi Araştırma Ve Uygulama Merkezi Dergisi, 2006, S. 20, s.105-115.

Dünyada Arabuluculuk Uygulamaları Konferansı. (2011). Ankara: Türkiye Barolar Birliği Yayını.

Gören, Zafer. (1992). “Türk-Alman Hukukunda Kişiliğin Korunması”. Anayasa Yargısı Dergisi. Sayı 9. s. 165-184. 
Gözler, Kemal. (2011). Anayasa Hukukunun Genel Teorisi. Cilt II. 1. Baskı. Bursa: Ekin Bas. Yay. Dağ.

Hukuk Uyuşmazlıklarında Arabuluculuk Kanunu, Resmi Gazete, 22.06.2012-28331.

İnceoğu, Sibel (2013). İnsan Hakları Avrupa Mahkemesi Kararlarında Adil Yargllanma Hakkl: Kamu ve Özel Hukuk Alanlarında Ortak Yargısal Hak ve İlkeler, Tıpkı Dördüncü Baskı, İstanbul: Beta Basım. Yay. Dağ.

Kur'an, Diyanet Vakfi Meali, Http://www.Kuranayetleri.Net/Nisa-Suresi/ Diyanet-Vakfi-Meali, (Erişim: 10.02.2018).

Parkinson, Lisa. (2017) Aile Arabuluculuğu: Yeni Aile Adalet Sistemine Dair Uygun Uyuşmazlık Çözüm Yöntemi. Adalet Bakanlığı Çevirisi-Nikbinlik Tercüme Ofisi, Sor. Ed. Av. Arabulucu Yonca Fatma Yücel.

Şen, Yusuf. (2012). "İslam Hukukunda Arabuluculuk". Hitit Üniversitesi Ilahiyat Fakültesi Dergisi. C. 11. S: 22. s. 105-135.

Tanrıver, Süha. (2006). "Hukuk Uyuşmazlıkları Bağlamında Alternatif Uyuşmazlık Çözüm Yolları Ve Özellikle Arabuluculuk”. TBBD. S. 64. s. $151-177$.

TÜIK, Evlenme Ve Boşanma İstatistikleri (2016). Http://Www.Tuik.Gov.Tr/ Prehaberbultenleri.Do?İd=24642, (Erişim: 19.02.2018).

Türkarslan, Nesrin. (2007). "Boşanmanın Çocuklar Üzerine Olumsuz Etkileri ve Bunlarla Başetme Yolları”, Aile ve Toplum Dergisi. Yıl: 9. Cilt: 3. Sayı: 11. s. 99-108.

Yargitay Hukuk Genel Kurulu Kararı, E. 2014/2-889, K. 2015/2011, T. 30.09.2015. 